\title{
COUNSELS, COUNCILS AND LUNCH: \\ PREVENTING ABUSE OF THE POWER TO \\ APPOINT INDEPENDENT COUNSELS
}

\author{
PETER M. RYAN†
}

\section{INTRODUCTION}

On July 14, 1994, Judge David B. Sentelle of the United States Court of Appeals for the District of Columbia Circuit ("D.C. Circuit") ate lunch in the Senate dining room with Republican North Carolina Senators Lauch Faircloth and Jesse Helms. Judge Sentelle later described the lunch as nothing more than a visit with old friends, the discussion ranging from prostate problems to country music. ${ }^{1}$ At the time of the lunch, however, Judge Sentelle was a member of the Court of Appeals "Division to Appoint Independent Counsels" ("Special Division"), a three-judge panel which makes such appointments purșuant to the Ethics in Government Act of 1978 ("Ethics Act"). ${ }^{2}$ The Special Division was then considering the appoint-

† B.A. 1987, Princeton University; M.F.A. 1990, New York University; J.D. Candidate 1997, University of Pennsylvania. I would like to thank Professor Stephen Burbank for his comments on an earlier draft and Pilar Ramos for her wonderful editing. I would also like to thank the Miami burglars who stole an earlier draft from the trunk of Pilar's car last July. As they never sent me any comments, I assume they thought it was okay.

I See Frank J. Murray, High Court Rejects Probe of Judge in Selection of Whitewater Counsel, WASH. TIMES, May 31, 1995, at A8. Before becoming a federal judge, Sentelle was chairman of the Mecklenberg County Republican Party in North Carolina. He worked on the election campaign of Senator Helms and was a member of the National Congressional Club, a political action committee that Helms helped organize. See Marcia Coyle, Panel That Chose Starr Has Conservative Ties, NAT'L L.J., Aug. 22, 1994, at A13, A13. President Reagan appointed Sentelle to the District Court for the Western District of North Carolina in 1985, and to the D.C. Circuit in 1987.

${ }^{2}$ Pub. L. No. 95-521, 92 Stat. 1824 (1978) (codified as amended by the Independent Counsel Reauthorization Acts of 1983, 1987 and 1994, at 28 U.S.C. $\$ \S 49,591-99$ (1994)). The Chief Justice of the United States Supreme Court appoints the three members of the Special Division, one of whom must be a judge from the D.C. Circuit. See $\S 49$ (d). The other two members of the Special Division at the time were Judge Joseph T. Sneed of the Ninth Gircuit, a Nixon appointee, and Judge John D. Butzner of the Fourth Circuit, a Johnson appointee. See Coyle, supra note 1, at Al3.

In 1992, Bush Administration hostility and a threatened filibuster in the Senate-Republicans were angered by then-independent counsel Lawrence Walsh's longrunning Iran-Contra investigation-resulted in Congress's failure to reauthorize the Ethics Act. See John Bryant, The Resurrection of the Independent Counsel: The Case for the Reauthorization of Special Prosecutors, LEGAL TimES, May 24, 1993, at 25, 25. By 1993, with Democrats controlling both the White House and Congress, Senate Republican 
ment ${ }^{3}$ of an independent counsel ${ }^{4}$ to investigate investments by President Clinton and his wife, Hillary, in the Whitewater Development Corporation, and loans to the Clintons from the failed Madison Guaranty Savings \& Loan-the so-called "Whitewater" affair." Attorney General Janet Reno had requested that the Special Division reappoint Robert B. Fiske, Jr., ${ }^{6}$ the independent counsel she had chosen in January 1994. ${ }^{7}$ Senators Helms and Faircloth, who had

opposition to reauthorization evaporated. See Adam Clymer, Republicans in About-Face on Special Prosecutor Law, N.Y. TIMES, Nov. 18, 1993, at Al6 (quoting Senator Bob Dole (R-Kan.) as saying that, while he still doubted the need for the law, "if there was ever a need, it is when one party controls everything"). On June 30, 1994, President Clinton signed the Independent Counsel Reauthorization Act of 1994. See Pub. L. No. 103-270, 108 Stat. 732 (1994).

${ }^{3}$ See $\S 49$. For a description of the duties of the Special Division, see infra notes 39-49 and accompanying text.

${ }^{4}$ In general, government officials, the press and the public have used the terms "independent counsel," "special counsel," "special prosecutor" and "special attorney" interchangeably. The Ethics in Government Act of 1978 used the term "special prosecutor." See Pub. L. No. 95-521, tit. VI, § 602(a), 92 Stat. 1873, 1873 (1978). Congress substituted "independent counsel" for "special prosecutor" when it reauthorized the Act in 1983. See Act of Jan. 3, 1983, § 2, 96 Stat. 2039, 2039 (1983). A meaningful distinction lies not so much in the title or authority given to an appointee but in whether the Attorney General or the Special Division has made the appointment - that is, whether the appointee is truly independent of the office of the Attorney General.

${ }^{5}$ See generally Jeff Gerth, Clintons Joined $S$. $\mathcal{E} \mathrm{L}$. Operator in an Ozark Real-Estate Venture, N.Y. TrMES, Mar. 8, 1992, § 1, at 1; Jeff Gerth, Clintons Release Tax Data Showing Land Deal Losses, N.Y. TIMES, Mar. 26, 1994, § 1, at 1.

${ }^{6}$ See Letter to the Editor from Lawrence E. Walsh, No Need to Replace Whitewater Counsel, N.Y. TIMES, Aug. 14, 1994, § 4, at 14 ("After Congress finally re-enacted the Independent Counsel Act, the Attorney General petitioned the Special Division to select Mr. Fiske as its appointee.").

${ }^{7}$ See Independent Counsel: In re Madison Guar. Sav. \& Loan Ass'n, 59 Fed. Reg. 5321, 5321 (1994) (codified at 28 C.F.R. $\$$ 603.1) (stating the specific purpose of the appointment and the authority given to the new independent counsel). Reno's appointment of Fiske gave him the same authority as an independent counsel appointed by the Special Division. See Jurisdiction of the Independent Counsel, 28 C.F.R. § 603.1 (1994).

The Attorney General has power to appoint "special attorneys" under 28 U.S.C. $\S 543$ (1994). Reno appointed Fiske, a former United States Attorney and a Republican, on January 20, 1994, during the Ethics Act hiatus. She initially opposed Republican demands that she appoint a Whitewater investigator, maintaining that anyone she selected would be subject to charges of not being truly independent. See Robert L. Jackson, GOP Lawyer Picked to Probe Whitewater, L.A. TIMES, Jan. 21, 1994, at A32. Upon Fiske's appointment, Senator Alfonse M. D'Amato (R-N.Y.) described him as "one of the most honorable and most skilled lawyers anywhere." Id. Senator Dole commented that "people who know him think he is extremely well-qualified, is independent," but added, "some of the conservative Republicans have not been happy with him." Id. Dole was referring to opposition from conservatives on the Senate Judiciary Committee when former Attorney General Richard Thornburgh proposed 
both been critical of Fiske's stewardship as independent counsel, opposed his reappointment. ${ }^{8}$ Senator Faircloth had been an especially vocal Fiske critic during the six days of Whitewater hearings before the Senate Banking Committee, accusing Fiske of being unaggressive and of having conflicts of interest. ${ }^{9}$ At least a dozen Republican members of Congress had written to Judge Sentelle in opposition to Fiske's reappointment. ${ }^{10}$

On August 5, 1994, less than three weeks after Judge Sentelle's lunch with the two Senators, the Special Division replaced Fiske with Kenneth W. Starr, a former Bush Administration Solicitor General and D.C. Circuit Judge. ${ }^{11}$ Fiske was six months and some $\$ 2.5$ million into his investigation. ${ }^{12}$ In a brief opinion, the Special Division noted that it would be inconsistent with the Ethics Act for the Clinton Administration to play any part in the selection of the independent counsel. ${ }^{13}$

Starr, like Fiske, had a strong reputation for fairness. Unlike Fiske, however, Starr had strong Republican political affiliations. A member of the Reagan Administration Justice Department, he became the youngest judge ever named to the D.C. Circuit. ${ }^{14}$ After serving as the Bush Administration's Solicitor General, Starr headed the Quayle Commission on civil justice reform. ${ }^{15} \mathrm{He}$, too, could

Fiske as his top deputy during the Bush Administration. In 1987, Fiske had chaired the ABA committee that evaluated potential court nominees. Conservatives blamed Fiske for the ABA's tepid endorsement of Robert $H$. Bork's Supreme Court nomination, which was ultimately defeated in the Senate. Thornburgh's proposal of Fiske as his top deputy was ultimately dropped. See id.

${ }^{8}$ See Murray, supra note 1 , at A8.

' See Jerry Seper, The Whitewater Counsel Switch: GOP Groundswell Questioned Fiske's Effort in Inquiry, WASH. TIMES, Aug. 8, 1994, at Al. Fiske's alleged conflicts of interest included: his representation of Prudential-Bache and Smith Barney Shearson, firms involved in bond underwriting for the Arkansas Development Finance Authority while Clinton was the governor of Arkansas; his firm's representation of International Paper Co., which sold land to the Whitewater Development Corp.; his collaboration on two cases with Bernard Nussbaum, the White House counsel who had resigned because of Whitewater, while both were in private practice; his involvement in the defense of Clark Clifford and Robert Altman in the Bank of Credit and Commerce International (BCCI) case with Robert Bennett, Clinton's attorney in the Paula Corbin Jones sexual harassment suit. See id.

${ }^{10}$ See id.

${ }^{11}$ See In re Madison Guar. Sav. \& Loan Ass'n, Div. No. 94-1, slip op. at 4 (Special Division, D.C. Cir. Aug. 5, 1994).

12 See Henry J. Reske, A Judge's Lunch Debated, A.B.A. J., Nov. 1994, at 32, 32.

${ }^{13}$ See In re Madison Guar. Sav. \& Loan Ass'n, Div. No. 94-1, slip op. at 4 (Special Division, D.C. Cir. Aug. 5, 1994).

${ }^{14}$ See Kim Masters, Kenneth Starr, Supernova?, WASH. POST, Jan. 10, 1995, at E1.

${ }^{15}$ Coyle, supra note 1 , at A13. 
have been described as having potential conflicts of interest regarding Whitewater. These alleged conflicts, however, suggested a potential bias against, rather than for, the Clinton Administration. For instance, before being appointed by the Special Division, Starr had agreed to represent the Independent Women's Forum, a conservative Virginia legal policy group, in preparing a legal brief arguing against President Clinton's claim that during his tenure in office he should be immune from Paula Corbin Jones's sexual harassment suit. ${ }^{16}$ Unlike Fiske, Starr continued his private legal work while serving as independent counsel. In 1995, Starr was retained by the Lynde and Harry Bradley Foundation, a group that provides substantial funding to the Free Congress Foundation, American Spectator magazine and the Landmark Legal Foundation. ${ }^{17}$ Both the Free Congress Foundation and American Spectator provided a media forum for Clinton's fiercest Whitewater critics, while the Landmark Foundation provided legal counsel to Jean Lewis, the Resolution Trust Corporation investigator who was one of the President's chief Whitewater accusers. ${ }^{18}$

News of Judge Sentelle's lunch with Faircloth and Helms during the Special Division's appointment process prompted Democratic complaints and general concerns that the appointment of the new independent counsel was made for partisan political reasons. Senator Carl Levin (D-Mich.) wrote a letter to the Special Division urging the judges to ask Starr for an accounting of his recent partisan activities and to issue an opinion stating whether he could fairly investigate a case involving a Democratic president. ${ }^{19}$ The panel replied, in an unsigned unanimous opinion, that the reauthorized independent counsel statute did not give it the power to make such a request of Starr or to issue any opinions on his fitness to remain the Whitewater prosecutor. ${ }^{20}$ Judge Sentelle, when ques-

${ }^{16}$ See David Johnston, Special Counsel Linked to Suit Against Clinton, N.Y. TIMES, Aug. 12, 1994, at Al4. Starr later decided against writing the brief. See id. After his appointment, Starr tried to counter accusations of partiality by adding Samuel Dash, former chief counsel to the Senate Watergate committee, as an ethics counsel to his staff. See Stephen Labaton, Whitewater Prosecutor Adding Ethics Counsel to Allay Criticism, N.Y. TIMES, Oct. 6, 1994, at A23.

${ }_{17}$ See Sam Skolnik, Kenneth Starr's Conservative Conflict?, LEGAL TIMES, Oct. 23, 1995, at 1 .

18 See id.

${ }^{19}$ See David Johnston, Three Judges Spurn Protest on Whitewater Prosecutor, N.Y. TIMES, Aug. 19, 1994, at A16.

${ }^{20}$ See In re Madison Guar. Sav. \& Loan Ass'n (Levin Letter/Motion), Div. No. 941, slip op. at 2 (Special Division, D.C. Cir. Aug. 18, 1994). 
tioned about the lunch with the Senators, replied in a letter to the Washington Post that, "[t]o the best of [his] recollection nothing in these discussions concerned independent counsel matters."

In an unprecedented action, five former $A B A$ presidents issued a joint statement addressed to the Special Division, asking the three judges to act in an impartial manner when making future appointments. ${ }^{22}$ The former ABA presidents described the meeting as "'unfortunate, to say the least,"”23 and stated:

"Whether or not Mr. Fiske's replacement by Mr. Starr was discussed, the meeting gives rise to the appearance of impropriety and the public is left in doubt. ... The special court must make sure in the future that its selections of independent counsel are not just objective, but also appear to be objective, and to be made without regard to political considerations. ${ }^{\text {24 }}$

They did not, however, call for Starr's resignation because they had the "'utmost confidence in [his] integrity and objectivity." 25 In another response to the lunch meeting, two private citizens filed formal complaints with the chief judge of the D.C. Circuit, Judge Harry T. Edwards, seeking disciplinary action against Judge Sentelle.26 The complaints were filed pursuant to the Judicial Councils Reform and Judicial Conduct and Disability Act of 1980 ("Judicial Conduct Act"). ${ }^{27}$

On November 1, 1994, Judge Edwards dismissed the complaints as not conforming with the substantive disciplinary standard of the Judicial Conduct Act-the complainants failed to allege, as required by statute, that Sentelle had engaged in conduct "prejudicial to the effective and expeditious administration of the business of the courts." ${ }^{28}$ In the opinion, Judge Edwards emphasized that Judge

${ }^{21}$ Reske, supra note 12 , at 32.

${ }^{22}$ See Susan Schmidt, Former ABA Presidents Criticize Panel That Chose Starr, WASH. POST, Sept. 27, 1994, at A9. The five former ABA presidents were: Chesterfield Smith (1973-1974), W. Reece Smith, Jr. (1980-1981), Robert MacGrate (1987-1988), Robert D. Raven (1988-1989) and John J. Curtin, Jr. (1990-1991). See Reske, supra note 12, at 32.

${ }^{23}$ Reske, supra note 12, at 32 (quoting the joint statement).

${ }^{24} \mathrm{Id}$. (quoting the joint statement).

${ }^{25} \mathrm{Id}$. (quoting the joint statement).

${ }^{26}$ See Toni Locy, Former ABA Leaders Express Surprise at Response to Complaints About Judge, WASH. POST, Nov. 3, 1994, at A9.

${ }^{27}$ Pub. L. No. 96-458, 94 Stat. 2035 (1980) (codified at 28 U.S.C. $\$ \S 331-32,372$, 604 (1994)).

${ }^{28} 28$ U.S.C. § 372(c) (1) (1994); In re Charge of Judicial Misconduct or Disability, 39 F.3d 374, 375 (Judicial Council, D.C. Cir. 1994). For a description of the complaint procedure under the Judicial Conduct Act, see infra notes 125-32 and 
Sentelle's behavior could not be subject to discipline under the Judicial Conduct Act because the primary business of the courts is the resolution of "Cases" and "Controversies" within the jurisdiction conferred by Article III of the Constitution, and because " $[t]$ he Special Division's authority to appoint an independent counsel arises not from Article III . . . but from the Appointments Clause of Article II, Section 2." ${ }^{29}$ The opinion stated that because the Ethics Act is silent as to whether, or to what extent, members of the Special Division may solicit or consider the views of outsiders, the panel was free to consult opponents of the President in making the appointment. ${ }^{30}$ Judge Edwards concluded:

There may be some members of society who would question the actions of the accused judge, for they have a pristine (albeit arguably naive) view of the appointment process. But this is irrelevant. The simple point here is that, even accepting the complaints as true for the purposes of this analysis, the judge who has been accused in this case would have violated no provision of law or ethical Canon. There is no basis whatsoever for proceedings against this judge. ${ }^{31}$

A majority of the D.C. Circuit Judicial Council endorsed Judge Edwards's dismissal of the complaints. ${ }^{32}$ On May 30, 1995, the Supreme Court denied a request, without comment, to overturn the dismissal. ${ }^{33}$

This Comment discusses the interplay between two Watergateinspired statutes: the Judicial Conduct Act and the Ethics Act. Both statutes were attempts to address misconduct by public officials. ${ }^{34}$

accompanying text.

${ }^{29}$ In re Charge of Judicial Misconduct, $39 \mathrm{~F} .3 \mathrm{~d}$ at 378.

30 See id. at 381-82 (stating that the fact that "those persons consulted might be political opponents of the President or his party should not expose the selection process to an anti-administration taint").

${ }^{31}$ Id. at 382-83.

32 See Gilbert Cranberg, Speaking of Ethics, N.Y. TIMES, Aug. 11, 1995, at A29.

${ }^{33}$ See In re Mandanici, $115 \mathrm{~S}$. Ct. 2270 (1995) (denying the petition for writ of mandamus). Proceedings under the Judicial Conduct Act are administrative, not judicial, in nature. The statute creates no avenue for appeal to the Supreme Court, and a Judicial Council's endorsement of a chief judge's dismissal of a complaint normally terminates all proceedings. See infra notes 125-32 and accompanying text (describing the administrative process of the Judicial Conduct Act).

${ }^{34}$ See In re Sealed Case, 838 F.2d 476, 506 (D.C. Cir.) ("The Watergate crisis is, of course, [the Ethics Act's] genesis . ... .), rev'd sub nom. Morrison v. Olson, 487 U.S. 654 (1988); Stephen B. Burbank, Procedural Rulemaking Under the Judicial Conuncils Reform and Judicial Conduct and Disability Act of 1980, 131 U. PA. L. REv. 283, 292 (1982) (describing how, during Senate debates on an early version of the judicial 
This Comment argues that the Judicial Conduct Act does and should apply to the conduct of members of the Special Division, notwithstanding the fact that they make appointments pursuant to Article II. Part I briefly describes the procedures of the Ethics Act and the Supreme Court's decision in Morrison $v$. Olson, ${ }^{35}$ which determined the constitutionality of the Ethics Act. In particular, Part I illustrates how Justice Scalia's dissent in Morrison perceived the potential for abuse of the appointment power by the Special Division. Part II discusses in detail Chief Judge Edwards's opinion dismissing the complaints against Judge Sentelle under the Judicial Conduct Act. Part III examines possible amendments to the Ethics Act. It concludes that there is no practical, effective way to amend the Ethics Act to prevent Special Division abuse of the appointment power without undermining the very purpose of the Act: the expeditious appointment of a temporary prosecutor who is truly independent from the Executive Branch to investigate potential criminal behavior by members of that branch. Part IV argues that Judge Edwards's formalistic conception of the scope of the Judicial Conduct Act is inconsistent with the Act's legislative history, purpose and practice. It concludes that applying the Judicial Conduct Act to the actions of judges on the Special Division is the simplest, most sensible way to ensure the proper functioning of the Ethics Act.

\section{The Ethics ACt, THE SpeCIAL DIVISION} AND MORRISON V. OLSON

\section{A. Ethics Act Procedures and the Special Division}

Title VI of the Ethics in Government $\mathrm{Act}^{36}$ provides for the appointment of an independent counsel for the investigation and, if necessary, the prosecution of certain high-ranking government officials for violations of federal criminal law. ${ }^{37}$ The statute requires

disciplinary legislation, "Watergate was on everybody's mind").

${ }^{35} 487$ U.S. 654 (1988).

${ }^{36} 28$ U.S.C. $\$ \S 49,591-99$ (1994).

${ }^{37}$ Sections 591(a) and (c) (1) provide that the Act applies to violations of any "[f]ederal criminal law other than a violation classified as a Class B or $\mathbf{C}$ misdemeanor or an infraction." Individuals who may be investigated under the Act include the President, the Vice President, Cabinet officials, high-ranking officials in the Executive Office of the President and in the Justice Department, the Director and the Deputy Director of Central Intelligence, the Commissioner of Internal Revenue, and certain officials in the President's election or reelection campaign. See $\$ 591$ (b); Morrison, 487 U.S. at 660 n.2. 
the Attorney General to conduct a preliminary investigation whenever she receives "information sufficient to constitute grounds to investigate whether any person [covered by the Act] may have violated Federal criminal law." 38

The Act's major innovation is the creation of a three-judge panel for the purpose of appointing independent counsels. ${ }^{39}$ When the Attorney General has completed her investigation, or when ninety days have elapsed, she must report to the Special Division. If she determines that "there are no reasonable grounds to believe that further investigation is warranted" and so notifies the Special Division, the panel "shall have no power to appoint an independent counsel with respect to the matters involved." 40 If, however, the Attorney General determines that there are reasonable grounds to believe that further investigation is warranted, she must submit an application to the Special Division for the appointment of an independent counsel. ${ }^{41}$

Upon receipt of the Attorney General's application, the Special Division "shall appoint an appropriate independent counsel and shall define that independent counsel's prosecutorial jurisdiction." ${ }^{22}$ The Act places few restrictions on the Special Division's selection: the panel must appoint an individual with "appropriate experience ... who will conduct the investigation and any prosecution in a prompt, responsible and cost-effective manner." ${ }^{43}$ To ensure an effective, thorough inquiry, the Act vests the Special Division's appointee with the full investigative and prosecutorial powers of the Attorney General. ${ }^{44}$

Beyond appointing the independent counsel and setting her jurisdiction, the Special Division's duties are mostly administrative.

$38 \S 591(\mathrm{a})$.

${ }^{39}$ See $\S 49$ (a) ("Three judges or justices shall be assigned ... to be the division of the court for the purpose of appointing independent counsels."). A division of the D.C. Circuit, the Special Division consists of three circuit court judges appointed for two-year terms by the Chief Justice of the United States Supreme Court. One of the judges must be from the D.C. Circuit, and no two of the judges may be from the same circuit. See § 49(d).

${ }^{40} \S 592(\mathrm{~b})(1)$.

${ }^{41}$ See $\S 592(\mathrm{c})(1)(\mathrm{A})$.

$42 \S 593(\mathrm{~b})(1)$. The Attorney General's application must contain "sufficient information" to assist the panel in selecting the independent counsel and defining her jurisdiction. See $\$ 592(d)$. Either the Attorney General or the independent counsel may subsequently apply to the Special Division for an expansion of the initially determined jurisdiction. See $\$ 593(\mathrm{c})$.

${ }^{43} \S 593(\mathrm{~b})(2)$.

44 See $\$ 594(\mathrm{a})$. 
The panel receives periodic reports from the independent counsel and decides whether and how much of the reports to release to the public. ${ }^{45}$ Although the Attorney General has power under $\S 596(a)(1)$ to remove the independent counsel "for good cause," this decision is not subject to review by the Special Division, but rather in a civil action in the D.C. District Court. ${ }^{46}$

The office of the independent counsel terminates when it notifies the Attorney General that it has completed or substantially completed its investigation or prosecution. ${ }^{47}$ In addition, the Special Division may, acting either on its own initiative or at the suggestion of the Attorney General, terminate the office of the independent counsel if it finds that the investigation is "completed or so substantially completed that [termination] would be appropriate. ${ }^{n 8}$

Finally, to preserve the appointee's independence even from the Special Division, the Act forbids any member of the panel from participating in any judicial proceeding that involves the independent counsel's official duties. ${ }^{49}$ The Act thus creates a panel of Article III judges with limited non-Article III powers, the most central of which is the power to make an appointment that is normally made by the Executive Branch.

\section{B. In re Sealed Case and Morrison v. Olson}

Ten years after the passage of the Ethics Act, the Special Division's appointment power and its alleged effect on the separation of powers prescribed by the Constitution came under constitutional attack. The D.C. Circuit, in In re Sealed Case, ${ }^{50}$ declared the Ethics Act unconstitutional. The Supreme Court, in Morrison v. Olson, ${ }^{51}$ reversed the D.C. Circuit's decision. Both the Court of Appeals's opinion and Justice Scalia's dissent in Morrison recognized the poten-

${ }^{45}$ See $\S 594(\mathrm{~h})$.

46 See $\$ 596$ (a) (3). The original version of the Act allowed the Special Division to hear such an action. See Morrison v. Olson, 487 U.S. 654, $664 \mathrm{n} .8$ (1988) (noting that "[u]nder the Act as originally enacted, an independent counsel who was removed could obtain judicial review of the Attorney General's decision in a civil action commenced before the Special Division").

${ }^{47}$ See $\S 596(b)(1)$.

${ }^{43} \S 596$ (b) (2). The Supreme Court has described this provision as a device for removing from the public payroll an independent counsel who has served his purpose, but is unwilling to acknowledge the fact." Morrison, 487 U.S. at 683.

${ }^{49}$ See 28 U.S.C. § 49(f).

${ }^{50} 838$ F.2d 476 (D.C. Cir.), rev'd sub nom. Morrison v. Olson, 487 U.S. 654 (1988).

${ }^{51} 487$ U.S. 654 (1988). 
tial for abuse of the Special Division's powers under the Act. The concerns raised about the Special Division's replacement of Robert Fiske with Kenneth Starr, including the complaints filed against Judge Sentelle, were responses to the perception that precisely such an abuse of power had occurred in the Whitewater investigation.

The D.C. Circuit, in an opinion by Judge Silberman, rested its decision in In re Sealed Case on the ground that the Ethics Act was inconsistent with the Appointments Clause of Article II. The court stated that because the independent counsel in the case was not an inferior officer, the power to appoint her could not be vested constitutionally in a court of law. ${ }^{52}$ Anticipating that the Supreme Court would review its decision, however, the Court of Appeals also decided the appellants' ${ }^{33}$ other constitutional claims: it held, first, that the Ethics Act violated the Constitution because it impermissibly interfered with the President's duty to "take Care that the Laws be faithfully executed," ${ }^{, 54}$ and second, that the Act violated Article III and the separation of powers doctrine because it entrusted an Article III court with an executive function. ${ }^{55}$

In its analysis of the latter alternative ground for the decision, the court stated that the doctrine of separation of powers could be violated either when "[o]ne branch ... interfere[s] impermissibly with [another's] performance of its constitutionally assigned function,", or "when one branch assumes a function ... more properly . . . entrusted to another." ${ }^{\prime 56}$ Given that Article III limits the power of the

${ }^{52}$ See In re Sealed Case, 838 F.2d at 487. Under the Constitution, courts of law may appoint only inferior officers. The Appointments Clause provides that the President:

shall nominate, and by and with the Advice and Consent of the Senate, shall appoint Ambassadors, other public Ministers and Consuls, Judges of the supreme Court, and all other Officers of the United States, whose Appointments are not herein otherwise provided for, and which shall be established by Law; but the Congress may by Law vest the Appointment of such inferior Officers, as they think proper, in the President alone, in the Courts of Law, or in the Heads of Departments.

U.S. CONST. art. II, $\S 2$, cl. 2.

${ }^{53}$ The District Court had held the Act to be constitutional. See In re Sealed Case, 665 F. Supp. 56, 62 (D.D.C. 1987) (mem.).

${ }^{54}$ U.S. CONST. art. II, § 3; see also In re Sealed Case, 838 F.2d at 487 . The court found that the Act's appointment, removal and supervisory provisions "so deeply invade[d] the President's executive prerogatives and responsibilities and so jeopardize[d] individual liberty as to be unconstitutional." Id. at 511.

${ }^{35}$ See In re Sealed Case, 838 F.2d at 511.

${ }^{36}$ Id. (quoting INS v. Chadha, 462 U.S. 919, 963 (1983) (Powell, J., concurring) (citations omitted)). 
judiciary to resolving "Cases" and "Controversies," it inappropriate that the Act assigned to the Special Division the power not only to appoint the independent counsel but also the duty to supervise her activities-powers traditionally reserved to the Executive Branch. ${ }^{58}$

This supervisory role, like many executive-type duties, almost inevitably involved the Special Division in decisionmaking "in the context of swirling controversy in which various factions hoped for opposing outcomes" and where decisions "necessarily rested on indeterminate considerations of policy and on information brought to the decisionmaker's attention through various avenues, including ex parte communications. ${ }^{.59}$ The court feared that such intimate involvement in the supervision of a politically charged investigation undermined the status of the judiciary as a neutral forum for dispute resolution. ${ }^{60}$

In addition to concerns about the appearance of partiality, the court suggested that involving Article III judges too deeply in executive power could lead to judicial abuse of that power. The court quoted The Federalist Papers. "Were [the judicial power] joined to the executive power, the judge might behave with all the violence of an oppressor." "61 The Ethics Act, the court believed, vested the Special Division with powers which created the appearance of partiality and the potential for abuse.

The Supreme Court, however, disagreed. In Morrison v. Olson, ${ }^{62}$ Chief Justice Rehnquist's opinion for the majority reversed the D.C. Circuit on each of its three grounds for decision. The Court held that the independent counsel was an inferior officer, and that thus, there was no conflict with the Appointments Clause. ${ }^{63}$ The Court

${ }^{57}$ U.S. CONST. art. III, § 2.

${ }^{58}$ See In re Sealed Case, 838 F.2d at 511-12 ("[T]he act impermissibly takes a central responsibility from the Executive Branch in violation of Article II.").

${ }_{59}$ Id. at 513. The political controversies surrounding both the Iran-Contra investigation and the Whitewater investigation lend credence to this assertion.

${ }^{60}$ See id. at 512 (stating that the duties prescribed for the Special Division judges under the Ethics Act could overinvolve them "in the process of policy and thereby weaken confidence in the disinterestedness of their judicatory functions" (quoting Felix Frankfurter, Advisory Opinions, in I ENCYCLOPEDIA OF THE SOCIAL SCIENCES 475, $478(1930)))$.

${ }^{61}$ Id. at 516 (quoting THE FEDERALIST No. 48, at 334 (James Madison) (J. Cooke ed., 1961) (quoting Montesquieu)).

62487 U.S. 654 (1988).

${ }^{63}$ See id. at 670-75. The Court reasoned that the independent counsel was an inferior officer because she was subject to removal by a higher executive branch official and had limited duties, jurisdiction and tenure under the Ethics Act. See id. 
also held that the Ethics Act did not impermissibly interfere with the functions of the Executive Branch ${ }^{64}$ and did not violate Article III. ${ }^{65}$

With regard to the Article III concerns expressed by the Court of Appeals, the Court reasoned that if Congress wanted to remove the appointing authority from the Executive Branch-for fear of the conflicts of interest that could arise in situations where the Executive Branch is called upon to investigate one of its own high-ranking officers-"the most logical place to put it was in the Judicial Branch." ${ }^{66}$ This transfer of Article II appointment power to a panel of Article III judges did not, the Court believed, "pose[] any threat to the impartial and independent federal adjudication of claims within the judicial power of the United States." "67

The Court based this conclusion on the fact that the Ethics Act did not give the Special Division power to review any of the independent counsel's actions or any of the Attorney General's actions with regard to the counsel. ${ }^{68}$ Also, the Act prohibited members of the Special Division from participating in "'any judicial proceeding concerning a matter involving the independent counsel." 69 Thus, the Court considered the Special Division "sufficiently isolated ... from the review of the activities of the independent counsel so as to avoid any taint of the independence of the Judiciary such as would render the Act invalid under Article III."

The Court's measure of what types of activity could pose a threat to the status of the judiciary as a neutral forum for the resolution of "Cases" and "Controversies" was markedly different from that expressed in the D.C. Circuit's opinion in In re Sealed Case. In the Court's analysis, only judicial review by the Special Division-of either the actions of the independent counsel or of any judicial proceedings related to matters investigated by the counsel-could constitute a threat to the impartiality of Article III judges. ${ }^{71}$ That is, only

at $671-72$.

${ }^{64}$ See id. at $685-96$.

${ }^{65}$ See id. at $677-85$.

${ }^{66}$ Id. at 677.

${ }^{67}$ Id. at 683 (quoting Commodity Futures Trading Comm'n v. Schor, 478 U.S. 833, 850 (1986)).

${ }^{68}$ See id.

${ }^{69} I d$. at $683-84$ (quoting 28 U.S.C. $\$ 49$ (f) (1994)); see also 28 U.S.C. § 596(a)(3) (1994).

${ }^{70}$ Id. at 684.

${ }^{7}$ See id. at 684-85. 
Article III behavior could weaken public confidence in the disinterestedness of the judiciary.

In the D.C. Circuit opinion, Judge Silberman put forth a broader measure. The Special Division's activities pursuant to its purported Article II appointment power, if such activities involved the judges too intimately in "swirling [political] controvers[ies],"72 could pose a threat to the perception of a neutral judiciary. The lower court opinion recognized the threat that the appearance of political bias could pose, even if this appearance arose outside of an Article III proceeding. The Supreme Court opinion ignored this possibility. ${ }^{73}$ Judge Silberman, at the end of his opinion, quoted Judge Skelly Wright: "The need to preserve judicial integrity is more than just a matter of judges satisfying themselves that the environment in which they work is sufficiently free of interference to enable them to administer the law honorably and efficiently. Litigants and our citizenry in general must also be satisfied." "74

Justice Scalia's lone dissent in Morrison directly addressed the problem of the Special Division's potential to abuse its appointment power under the Ethics Act. The main thrust of Scalia's argument accorded with Judge Silberman's argument: the Ethics Act and the majority's decision upholding the constitutionality of the Act replaced the principle of separation of powers, specifically, Article II's requirement that " $[t]$ he executive Power ... be vested in a President of the United States of America,"75 with a standardless balancing test. ${ }^{76}$ Near the close of his dissent, however, Scalia addressed "the fairness of the process" that those covered by the Act

${ }^{72}$ In re Sealed Case, 838 F.2d 476, 513 (D.C. Cir. 1988).

${ }^{73}$ Judge Edwards's opinion in the dismissal of the complaints against Judge Sentelle echoes the Morrison majority's narrow measure of conduct that undermines public confidence in the impartiality of the judiciary. See In re Charge of Judicial Misconduct or Disability, 39 F.3d 374, 380 (Judicial Council, D.C. Cir. 1994) ("[I]n creating the Special Division, Congress recognized the difference between the appointment and judicial powers by making it clear that a judge who participates in the selection of an independent counsel while a member of the Special Division cannot thereafter participate in a judicial proceeding involving the independent counsel ...."); see also infra Part II.

74 In re Sealed Case, 838 F.2d at 517 (quoting Hobson v. Hansen, 265 F. Supp. 902, 931 (D.D.C. 1967) (Wright, J., dissenting)) (citation omitted).

${ }^{75}$ U.S. CONST. art. II, $\$ 1$, cl. 1.

${ }^{76}$ See Morrison v. Olson, 487 U.S. 654, 711 (1988) (Scalia, J., dissenting) ("What are the standards to determine how the balance is to be struck, that is, how much removal of Presidential power is too much? ... The most amazing feature of the Court's opinion is that it does not even purport to give an answer."). 
received. ${ }^{77}$ Noting initially "the vast power and the immense discretion that are placed in the hands of a prosecutor," ${ }^{78}$ Scalia asserted that the primary check against the abuse of this power and discretion is a political one-prosecutors are selected and can be removed by the President, and when prosecutors abuse their power the President pays the cost in political damage to his administration. ${ }^{79}$

The Ethics Act, however, created a process that is not in the full control of the Attorney General or any prosecutor appointed by the President. ${ }^{80}$ Any flaws, either in the independent counsel's selection or in her subsequent behavior, cannot be blamed on the President. $^{81}$ Here, Scalia articulated the same concerns raised six years later regarding Judge Sentelle's behavior on the Special Division in the Whitewater investigation:

An independent counsel is selected, and the scope of his or her authority prescribed, by a panel of judges. What if they are politically partisan, as judges have been known to be, and select a prosecutor antagonistic to the administration, or even to the particular individual who has been selected for this special treatment? There is no remedy for that, not even a political one. Judges, after all, have life tenure, and appointing a surefire enthusiastic prosecutor could hardly be considered an impeachable offense .... [E]ven if it were entirely evident that unfairness was in fact the result-the judges hostile to the administration, the independent counsel an old foe of the President, the staff refugees from the recently defeated administration-there would be no one accountable to the public to whom the blame could be assigned. ${ }^{82}$

While Justice Scalia was quick to add that he had the highest regard for the judges on the Special Division and that such abuses of power would rarely occur, he nonetheless asserted that the Ethics Act afforded unfair process to those it covered: "[T]he fairness of a process must be adjudged on the basis of what it permits to happen, not what it produced in a particular case." ${ }^{\text {3 }}$

Both Judge Silberman's opinion in In re Sealed Case and Justice Scalia's dissent in Morrison argued that the Ethics Act violated the

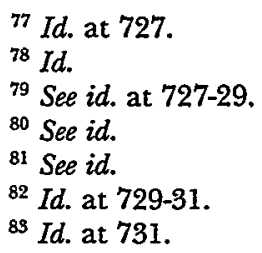


Constitution. Judge Silberman warned that, by giving executive power to a panel of Article III judges, the Act would mire judges in political disputes and thus undermine the public's confidence in the judiciary's impartiality in deciding "Cases" and "Controversies." Justice Scalia moved beyond appearances and warned that the Special Division could abuse its appointment power with a politically partisan choice for an independent prosecutor. Neither opinion won the day.

The remainder of this Comment addresses Justice Scalia's contention that no remedy exists for the abuse of Special Division appointment power. Judge Edwards's opinion dismissing the complaints against Judge Sentelle would seem to suggest that, indeed, no remedy exists.

\section{IN RE CHARGE OF JUDICIAL MISCONDUCT OR DISABILITY ${ }^{84}$}

The complaints ${ }^{85}$ before Judge Edwards alleged judicial misconduct by Judge Sentelle on the Special Division and sought relief under the Judicial Conduct Act. ${ }^{86}$ The principal substantive standard of the Judicial Conduct Act is that federal appellate, district, bankruptcy and magistrate judges will not "engage[] in conduct prejudicial to the effective and expeditious administration of the business of the courts." ${ }^{\text {87 }}$ Collectively, the complaints alleged: (1) that Judge Sentelle's lunch with Senators Faircloth and Helms and his receipt of and failure to disclose correspondence from other members of Congress ${ }^{88}$ constituted ex parte communications in violation of Canon 3(A) (4) of the Code of Conduct for United States Judges; ${ }^{89}$ and (2) that the lunch meeting that took place while

8439 F.3d 374 (Judicial Council, D.C. Cir. 1994).

${ }_{85}$ Judge Edwards identified three separate complaints in his opinion: Nos. 94-8, 94-9 and 94-10. See id. at 377. The press reported two complainants: Sarah Ruschaupt of Virginia and Francis Mandanici of Connecticut. See Murray, supra note 1 , at A8.

8628 U.S.C. $\$ \S 331-32,372,604$ (1994).

$87 \S 372(\mathrm{c})(1)$.

ss See supra note 10 and accompanying text.

${ }^{89}$ CODE OF CONDUCT FOR UNITED STATES JUDGES Canon 3(A) (4) [hereinafter CODE OF JUDICIAL CONDUCT] ("A judge should ... neither initiate nor consider ex parte ... communications on the merits, or procedures affecting the merits, of a pending or impending proceeding."). This Code was adopted in 1992 by the Judicial Conference of the United States, an annual gathering of the Chief Justice of the U.S. Supreme Court, the chief judge of each judicial circuit, the chief judge of the Court of International Trade, and a district judge from each judicial circuit. See 28 U.S.C. $\S 331$ (1994). The Code "governs the conduct of United States Circuit Judges, Court of International Trade Judges, Court of Federal Claims Judges, Bankruptcy Judges, and Magistrate Judges." CODE OF JUDICIAL CONDUCT n.l. 
Judge Sentelle was considering the appointment of the Whitewater independent counsel as well as Judge Sentelle's "judgment" in appointing Kenneth Starr created the "appearance of impropri-

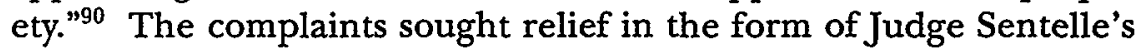
"voluntary retirement" from the Special Division, a review of the appointment of Starr, and a public reprimand for Judge Sentelle's misconduct. ${ }^{91}$

Judge Edwards, describing the complaints as "misguided," dismissed them on the ground that they did not conform with the Judicial Conduct Act. ${ }^{92}$ He relied on the facts that the Special Division made its appointment acting under the Appointments Clause of Article II and that no constitutional or ethical precept prohibited consultations during the appointment process. Also, Judge Edwards noted that nothing in the Ethics Act itself limited consultations by the Special Division. ${ }^{93}$

\section{A. The Jurisdictional Question}

Before dismissing the complaints, however, Judge Edwards addressed the question of whether a member of the Special Division could even be subject to disciplinary proceedings in the D.C. Circuit. This jurisdictional question seems to be, on its face, easy to answer. The section of the Ethics Act creating the Special Division explicitly describes it as "a division of the United States Court of Appeals for the District of Columbia." Thus, although two members of the Special Division are not from the D.C. Circuit, Judge Sentelle is a D.C. Circuit judge and, therefore, should be subject to disciplinary proceedings in his home circuit. ${ }^{95}$

While he ultimately did assume that jurisdiction existed for the D.C. Judicial Council to hear the complaints, Judge Edwards's

${ }^{90}$ In re Charge of Judicial Misconduct or Disability, 39 F.3d 374, 377 (Judicial Council, D.C. Cir. 1994) (citation omitted). The "appearance of impropriety" language is found in the Code of Judicial Conduct: "A judge should avoid impropriety and the appearance of impropriety in all activities." CODE OF JUDICIAL CONDUCT Canon 2.

${ }^{91}$ In re Charge of Judicial Misconduct, 39 F.3d at 377 . Voluntary retirement from Article III duties and public reprimand are two of the remedies available under the Judicial Conduct Act. See 28 U.S.C. $\$ 372$ (c)(6)(B) (iii), (iv) (1994).

${ }^{92}$ In re Charge of Judicial Misconduct, 39 F.3d at 376.

${ }^{93}$ See id.

9428 U.S.C. $\$ 49$ (a) (1994).

${ }^{95}$ See D.C. CIR. Judicial Misconduct OR DiSABILITY R. 1(c) commentary at 4 ("[T]he circuit in which a judge or magistrate holds office is the appropriate circuit in which to file a complaint."). 
analysis of this issue emphasized the separateness of the Special Division from the D.C. Circuit. He noted that the Special Division keeps its own records and establishes its own procedures. ${ }^{96} \mathrm{He}$ also noted that because the Special Division must include two judges who are not members of the D.C. Circuit, it cannot constitute a panel authorized to hear "Cases" or "Controversies" within the D.C. Circuit's jurisdiction. ${ }^{97}$ Notwithstanding these potential obstacles, Judge Edwards found jurisdiction because of Judge Sentelle's membership on the D.C. Circuit and because Judge Sentelle did not contest disciplinary proceedings in the D.C. Circuit. ${ }^{98}$ Judge Edwards also found support for his jurisdictional holding by analogizing Judge Sentelle's service on the Special Division to the case of a judge who is "visiting" another circuit and who is thus still subject to the disciplinary authority of his home circuit. ${ }^{99}$

Judge Sentelle, however, was not visiting another circuit. The Special Division, as noted above, is part of the D.C. Circuit; Judge Sentelle is a member of the D.C. Circuit. Judge Edwards's jurisdictional questions would make more sense if the subject judge in the complaints were one of the other two judges on the Special Division who was not from the D.C. Circuit.

A possible explanation for Judge Edwards's jurisdictional inquiry emerges from the sharp distinction he later draws between conduct by a judge under Article II and judicial conduct under Article III. It is primarily this distinction that Judge Edwards used as his justification in dismissing the complaints.

\section{B. Chief Judge Edwards's Article II/Article III Distinction for Purposes of the Judicial Conduct Act}

In addressing the central issue of whether the complaints against Judge Sentelle alleged "conduct prejudicial to the effective and expeditious administration of the business of the courts," 100 Judge Edwards initially noted that the primary business of the D.C. Circuit is the resolution of "Cases" and "Controversies" within the jurisdiction conferred by Article III. ${ }^{101}$ This fact, however, might not

${ }^{96}$ See In re Charge of Judicial Misconduct, 39 F.3d at 378.

97 See id.

${ }^{93}$ See id.

${ }^{99}$ See id.; see also D.C. GIR. JUDICIAL MISCONDUCT OR DiSABILITY R. I(c) commentary at 4 ("Complaints against a visiting judge from this circuit should be filed here.").

10028 U.S.C. $\$ 372$ (c) (1) (1994).

${ }^{101}$ In re Charge of Judicial Misconduct or Disability, $39 \mathrm{F.3d} \mathrm{374,} 378$ (Judicial 
dispose of the question, Judge Edwards continued, because of differing interpretations of the scope of the substantive standard governing actions under the Judicial Conduct Act. ${ }^{102}$ The "business of the courts" might be interpreted to apply only to Article III business; alternatively, the statute might also cover conduct having only an indirect prejudicial effect on the courts' judicial function. ${ }^{103}$

In the end, Judge Edwards found it unnecessary to determine the breadth of the statutory standard, "[f]or however broadly the statutory standard is to be read, complainants do not allege conduct by the subject judge that could have even an indirect prejudicial effect on the administration of the business of the courts." 104 Because the Special Division exercised Article II appointment power, and because this power is by its nature entrusted to the discretion of the appointing authority, safeguards such as the prohibition against ex parte contacts and the "appearance of impropriety" were mostly irrelevant. ${ }^{105}$ The appointment of an independent counsel by the Special Division was not an adversarial proceeding; thus, Judge Edwards reasoned, Judge Sentelle's conduct while on the Special Division could not have had even an indirect prejudicial effect on the administration of the business of the courts.

Finally, Judge Edwards dismissed the complaints against Judge Sentelle, noting that: the Ethics Act was silent as to whether, or to what extent, members of the Special Division could consult with outsiders in the course of making an appointment; it would make little sense in Judge Edwards's view to impose any restrictions; and, the Special Division's past practice had been to consult with outsiders. $^{106}$

\section{The Inconsistency Between Chief Judge Edwards's Jurisdictional Argu- ment and His Article II/Article III Distinction}

This Comment argues that, contrary to Judge Edwards's opinion, determining the breadth of the Judicial Conduct Act's substantive standard is necessary for the correct disposition of complaints about judicial conduct on the Special Division, regardless of the Article II

\footnotetext{
Council, D.C. Cir. 1994).

102 See id. at 378-79.

${ }^{103}$ See id. at 379.

${ }^{104}$ Id. (emphasis omitted).

105 See id. at 379-80.

106 See id. at 380-82.
} 
nature of the Division's appointment power. Part III argues that there is no effective way to amend the Ethics Act to address Special Division abuse of its appointment power without undermining the purposes of the Ethics Act. Part IV argues that a remedy under the Judicial Conduct Act would be effective, justifiable and attractively simple. The legislative history, purpose and practice of the Judicial Conduct Act suggest that Judge Sentelle's conduct during the appointment of Kenneth Starr should fall within that Act's scope.

Before turning to possible solutions, however, it is worth noting the inconsistency between Judge Edwards's jurisdictional analysis and his strict Article II/Article III distinction for purposes of the Judicial Conduct Act. Judge Edwards analogized Judge Sentelle's membership on the Special Division to the case of a judge "visiting" another circuit. ${ }^{107} \mathrm{~A}$ judge visiting another circuit would likely be performing Article III duties. The Special Division, however, only performs Article II duties. The fact that an Article III judge was involved in both situations made the situations sufficiently analogous for Judge Edwards to find jurisdiction under the Judicial Conduct Act. Later in the opinion, however, Judge Edwards asserted that Article II conduct by an Article III judge could in no way have even an indirect prejudicial effect on the administration of the business of the courts. ${ }^{108}$ Thus, Judge Edwards used Judge Sentelle's status as an Article III judge to assert jurisdiction under the Judicial Conduct Act over Article II conduct, but he ignored that same status in weighing whether Judge Sentelle's conduct on the Special Division could have had any effect on the business of the courts. Judge Edwards felt that there was a distinction, but to the general public, both situations involve an Article III judge. Why does Article III status matter in the jurisdictional realm but not in the real world?

\section{AN UNWIELDY SOLUTION: AMENDING THE ETHICS ACT}

Under Judge Edwards's conception of the Judicial Conduct Act, the only way to prevent judges on the Special Division from abusing their appointment powers to achieve partisan ends is to amend the Ethics Act in some way to restrict the Special Division's discretion. The Ethics Act as codified places few restrictions on the Special Division's appointment power beyond requiring that the appointee

107 See supra note 99 and accompanying text.

${ }^{108}$ See supra note 104 and accompanying text. 
have appropriate experience. ${ }^{109}$ Other instances involving judicial appointment power under Article II provide few, if any, helpful analogues. ${ }^{110}$

Placing some form of statutory restrictions on consultations by the Special Division in making their appointments would be both unrealistic and counterproductive. As Judge Edwards stated in his opinion: "It makes little sense to think that an authority acting pursuant to the Appointment Clause of Article II might be forbidden from consulting with others regarding candidates for appointment. It is hard to imagine how anyone would go about that task without seeking advice."111 The sheer difficulty and virtual absurdity of trying to decide beforehand whom to exclude-members of Congress?, anyone in a political party different from that of the President?-militates against such a course. In the past, the Special Division has routinely relied on discussions with judicial colleagues and former professional associates. ${ }^{112}$ Arguably, imposing such restrictions could result in the appointment of independent counsels in whose abilities the Special Division lacks confidence.

Other possible restrictions include requiring that the Special Division choose from a list of potential appointees it has compiled before the Attorney General applies for the appointment, or that the Special Division choose from among potential appointees supplied by the Attorney General. The first of these suggestions could prevent the Special Division from handpicking an independent counsel who would be unduly antagonistic to the subject of the investigation-a "guided missile." This potential benefit, however, is also a potential

${ }^{109}$ See supra note 43 and accompanying text.

${ }^{110}$ See, e.g., Young v. United States ex rel. Vuitton et Fils S.A., 481 U.S. 787, 809 (1987) (holding that the district court had authority to appoint a special prosecutor to prosecute defendants for contempt so long as "counsel for a party that is the beneficiary of a court order [was not] appointed as prosecutor in a contempt action alleging a violation of that order"); Ex parte Siebold, 100 U.S. 371, 398 (1879) (holding that an Act of Congress giving circuit courts power to appoint supervisors of elections did not violate separation of powers and placing no restrictions on this power); United States v. Solomon, 216 F. Supp. 835, 843 (S.D.N.Y. 1963) (holding that the appointment of a temporary United States Attorney by a district court does not violate separation of powers and placing no restrictions on the court's discretion).

${ }^{111}$ In re Charge of Judicial Misconduct or Disability, $39 \mathrm{~F} .3 \mathrm{~d}$ 374, 380 (Judicial Council, D.C. Cir. 1994).

112 See Katy J. Harringer, Independent Justice: The Federal Special PROSECUTOR IN AMERICAN POLITICS 150-51 (1992) ("Engaging a known quantity is a high priority, so, in practice, the 'old-boy network' plays a major role in the decision."). 
flaw: all of those on the prearranged list of appointees may be inappropriate choices for the particular type of case that arises. ${ }^{113}$

The second suggestion would give the Attorney General the power to propose, but not to appoint, whereas the Special Division would have the power to appoint, but not to propose. The Special Division could reject the Attorney General's candidates until the Attorney General came up with someone the Special Division felt was appropriately independent. The Attorney General would have an incentive to pick an independent candidate early on because it would be politically embarrassing to be repeatedly rejected.

While this suggestion has some appeal, it has two flaws. One is procedural. The appointment process could become a high-profile game of political "chicken," with the Attorney General stubbornly refusing to propose an independent candidate and the Special Division stubbornly refusing to appoint any of the proposed partisan candidates. This would not serve the public's desire for a prompt investigation. The second flaw is substantive. The Senate Report on the Ethics Act stated that "[t]he entire purpose of appointing a temporary special prosecutor is to get someone who is independent, both in reality and appearance, from the President and the Attorney General." ${ }^{114}$ Such a restriction on the Special Division's appointment power would arguably defeat the whole purpose of the Ethics Act.

The difficulty in amending the Ethics Act in a manner that would satisfactorily deter abuse of the Special Division's appointment power makes application of the Judicial Conduct Act seem not only appropriate but attractively simple. As Justice Scalia suggested, such abuses will rarely occur. ${ }^{115}$ Judicial awareness of the sensitivity of the Special Division's duties is required. An amendment to the Ethics Act is not.

${ }^{113}$ A former member of the Special Division described the importance of case type in the selection process: "First, we considered the type of case, and then we looked for lawyers, usually former prosecutors, who might fall into that type." Coyle, supra note 1 , at Al3 (quoting an unnamed former panel member).

${ }^{114}$ S. REP. NO. 170, 95th Cong., 2d Sess. 56, 65-66 (1977), reprinted in 1978 U.S.C.C.A.N. 4216, 4281-82.

${ }^{115}$ See Morrison v. Olson, 487 U.S. 654, 731 (1988) (Scalia, J., dissenting). 


\section{A SENSIBLE REMEDY For A RARE PROBlem:}

Abuse of SPECIAL DIVISION APPOINTMENT POWER SHOULD FaLl

WITHIN THE AMBIT OF THE JUdicial CONDUCT ACT

Justice Scalia, in his Morrison dissent, warned that there would be no remedy for Special Division abuse of the appointment power. ${ }^{116}$ This Part argues that partisan use of the appointment power granted to Article III judges under the Ethics Act constitutes "conduct prejudicial to the effective and expeditious administration of the business of the courts ${ }^{\text {117 }}$ under the Judicial Conduct Act. The possibility of judicial discipline under the Judicial Conduct Act would dampen the temptation to use the Article II power of the Special Division for partisan political ends. Article III judges would not mire themselves in the often swirling political disputes surrounding the use of independent counsels-Judge Silberman's fear in In re Sealed Case $^{118}$-and thus would not weaken public confidence in the judiciary. ${ }^{119}$ Moreover, such an interpretation of the Judicial Conduct Act neither undermines the purpose of the Special Division nor imprudently broadens the substantive scope of the Judicial Conduct Act.

After a brief description of the provisions of the Judicial Conduct Act, this Part examines in detail the substantive standard governing discipline under the Act. The legislative history of the Act, and practice under the Act, support the view that the complaints against Judge Sentelle's conduct were in conformity with $\S 372(\mathrm{c})(1)$.

\section{A. The Provisions of the Judicial Conduct Act}

A legislative child of the Watergate scandal, ${ }^{120}$ the Judicial Conduct Act-pithily named the Judicial Councils Reform and Judicial Conduct and Disability Act of $1980^{121}$-was intended to provide a supplement to the constitutional processes for impeachment and trial of federal judges. ${ }^{122}$ Concerns about judicial independence and

${ }^{116}$ See supra note 82 and accompanying text.

${ }_{117} 28$ U.S.C. \$ 372 (c) (1) (1994).

118838 F.2d 476 (D.C. Cir. 1988).

${ }^{119}$ See supra note 67 and accompanying text.

${ }^{120}$ See supra note 34.

12128 U.S.C. $\$ \S 331-32,372,604$ (1994). For a listing of the Act's misconduct and disability provisions, see $\$ 372(\mathrm{c})$.

${ }^{122}$ See Stephen B. Burbank, Politics and Progress in Implementing the Federal Judicial Discipline Act, 71 JUDICATURE 13, 13 (1987) (noting that the major controversies that led to the Act included "the need for and the constitutionality of any statutory process 
the constitutionality of disciplinary legislation for Article III judges resulted in this piece of compromise legislation. Congress did not include removal among the Act's remedies and gave responsibility for implementing the Act to the judiciary, acting through the preexisting judicial councils of each circuit. ${ }^{123}$ Since its passage, the Act has withstood both legal and scholarly challenges to its constitutionality. ${ }^{124}$

Under the Act, any person alleging that an appellate, district, bankruptcy or magistrate judge has engaged in "conduct prejudicial to the effective and expeditious administration of the business of the courts" may file a written complaint containing a brief statement of the facts with the Circuit Court of Appeals under whose jurisdiction the judge sits. ${ }^{125}$ After "expeditiously" reviewing the complaint, the chief judge may dismiss the complaint if it is not in conformity with the substantive standard of the Act, if it is directly related to the merits of a decision or procedural ruling, or if it is "frivolous." Alternatively, the chief judge may conclude the proceeding upon a finding that appropriate corrective action has been taken. ${ }^{126}$ If the

for addressing the problems of judicial misconduct or disability and . . . the fairness and adequacy of the means by which the federal judiciary had addressed the problems in the past").

123 See id.

${ }^{124}$ Proceedings under the Act against United States District Judge Alcee L. Hastings provided a years-long, comprehensive attack on the constitutionality of the Act. See Hastings v. Judicial Conference, 829 F.2d 91, 106 (D.C. Cir. 1987) (holding that the Act's standards of misconduct were not unconstitutionally vague or overbroad); In re Certain Complaints Under Investigation by an Investigating Comm. of the Judicial Council of the Eleventh Circuit, 783 F.2d 1488, 1505-16 (11th Cir. 1986) (holding, in an action by Judge Hastings's staff to quash subpoenas, that the Act did not violate separation of powers); Hastings $v$. Judicial Conference, 770 F.2d 1093, 1103 (D.C. Cir. 1985) (holding that claims that the Act was unconstitutional on separation of powers and due process grounds, and as applied, were premature). Judge Edwards believes that the Act is unconstitutional. See Harry T. Edwards, Regulating Judicial Misconduct and Divining "Good Behavior" for Federal Judges, $87 \mathrm{MICH}$. L. REV. 765, 766 (1989) ("[T] he only constitutionally permissible way to regulate judicial misconduct and disability that does not involve impeachable action is through a system of judicial self-regulation unencumbered by any form of congressional interference."). For other criticism of the Act's constitutionality, see Lynn A. Baker, Note, Unnecessary and Improper: The Judicial Councils Reform and Judicial Conduct and Disability Act of 1980, 94 YALE L.J. 1117, 1118 (1985) (arguing that the Act violates the Constitution's allocation of powers by requiring the judicial councils and the Judicial Conference to exercise a power of scrutiny over their Article III colleagues, which the Constitution promises that only Congress will exercise).

${ }^{125}$ See $\$ 372(c)(1)(4)$.

${ }^{126}$ See § 372(c) (3). 
chief judge decides neither to dismiss nor to conclude the proceeding, the chief judge appoints himself and an equal number of circuit and district judges of the circuit to a special committee to investigate the matter. ${ }^{127}$

After an investigation, the special committee files a report of its findings and recommendations with the circuit's judicial council. ${ }^{128}$ The judicial council may conduct a further investigation and take "appropriate" action. ${ }^{129}$ In addition, the council may refer the complaint, the record and its recommendations to the Judicial Conference of the United States. ${ }^{130}$ The council is obligated to send the complaint to the Judicial Conference if it believes the judge has engaged in conduct that might constitute grounds for impeachment or if the council cannot justly resolve the complaint. ${ }^{131}$ Complainants and subject judges may petition the judicial council for review of the chief judge's action, or, if aggrieved by the council's action, they may petition the Judicial Conference for discretionary review. Orders of the Judicial Conference are final. ${ }^{132}$

In the matter of the charges against Judge Sentelle, Judge Edwards dismissed the complaints as not in conformity with the Act's substantive disciplinary standard. ${ }^{133}$ The complainants petitioned the Judicial Council of the D.C. Circuit, which endorsed the dismissal. ${ }^{134}$

\section{B. The Substantive Standard of the Judicial Conduct Act}

The substantive standard governing the imposition of discipline under the Judicial Conduct Act has not lent itself to easy or consistent interpretation. ${ }^{135}$ What constitutes "conduct prejudicial to

${ }^{127}$ See $\$ 372(\mathrm{c})(4)$.

${ }^{128}$ See $\S 372(\mathrm{c})(5)$.

${ }^{129} \S 372(c)(6)$. Courses of action that the council may consider include: certifying disability; requesting voluntary retirement; ordering that no cases be assigned to the judge for a time; private or public reprimand or censure; other appropriate action excluding removal. See id.

${ }^{130}$ See $\S 372(\mathrm{c})(7)(\mathrm{A})$.

131 See $\$ 372$ (c) (7) (B). If there may be grounds for impeachment, the council must also certify and transmit the record and its determination to the House of Representatives. See § 372(c)(8).

132 See $\$ 372(c)(9)-(10)$.

${ }^{133}$ See In re Charge of Judicial Misconduct or Disability, 39 F.3d 374, 376 (Judicial Council, D.C. Cir. 1994).

${ }^{134}$ See supra note 32.

${ }^{135}$ See Jeffrey N. Barr \& Thomas E. Willging, Decentralized Self-Regulation, Accountability, and Judicial Independence Under the Federal Judicial Conduct and Disability Act of 
the effective and expeditious administration of the business of the courts" 136 was a matter of dispute during the formulation of the Act and has continued to be so in its application by the judicial councils. ${ }^{137}$ Should the standard be interpreted narrowly or broadly? Does it cover only judicial conduct on the bench or is some conduct off the bench also covered? Does the Act address only administrative efficiency or does it also cover conduct that brings the judicial office into disrepute?

In a sense, the debate over the scope of the disciplinary standard tracks the differing views of the Special Division expressed by Chief Justice Rehnquist in Morrison and Judge Silberman in In re Sealed

1980, 142 U. PA. L. REv. 25, 73 (1993) ("With so vague and unelaborated a standard of misconduct, uncertainty about its contours is probably inevitable."); Burbank, supra note 122, at 15 ("The major substantive question-the types of conduct subject to disciplinary action-remains in large part unanswered.").

${ }^{136} \S 372(c)(1)$.

137 See Burbank, supra note 34, at 322 ("The problem of evaluating complaint dismissals is exacerbated by the Act's substantive ambiguity [and] the unavailability to the public of dismissal orders ...."). There is no requirement under the Act that a chief judge's dismissal order or a council's order disposing of a petition for review be made available to the public. See $\$ 372$ (c)(15) (requiring that orders issued by a judicial council, the Judicial Conference or the standing committee be "made available to the public through the appropriate clerk's office of the court of appeals for the circuit"); see also Burbank, supra note 34, at $322 \mathrm{n} .166$ ("There is no requirement that either a chief judge's order dismissing or closing a complaint or a council's order disposing of a petition for review be made publicly available.").

In 1986, a special committee of the Conference of Chief Judges published nonbinding illustrative rules for the Act. See Burbank, supra note 122, at 14 (noting that the illustrative rules "appeared at a time when federal judicial discipline [wa]s in the news again"). Illustrative Rule 17 called for circuits to make orders public on a national basis, apparently in an effort to create a common law under the Act. See ILLUSTRATIVE R. GOVERNING COMPLAINTS OF JUDICIAL MISCONDUCT \& DISABILITY 17 (1986) [hereinafter IlLUSTRATIVE R.]. After an initial response from the circuits, however, publication has waned. See Barr \& Willging, supra note 135, at 85-88 (noting that "little evidence of the development of a common law under the Act exists," and that "[d]issemination of information about interpretations of the Act ... seems notably absent").

The Judicial Conference Committee to Review Circuit Council Conduct and Disability Orders revised the Illustrative Rules in 1991 in response to amendments to the Judicial Conduct Act under the Judicial Discipline and Removal Reform Act of 1990, Pub. L. No. 101-650, tit. IV, 104 Stat. 5122 (1990). See Memorandum from the Committee to Review Circuit Council Conduct and Disability Orders of the Judicial Conference of the United States to Chief Judges, United States Courts of Appeals, United States Court of International Trade and United States Claims Court 1 (Aug. 15,1991 ) (on file with author). A newly revised version of the Rules should be published sometime in 1996. See Letter from Jeffrey N. Barr, Assistant General Counsel, Administrative Office of the United States Courts, to Peter M. Ryan I (May 7,1996 ) (on file with author). Hereinafter, this Comment will make reference to the 1991 version of the Illustrative Rules. 
Case. Justice Rehnquist reasoned that the Special Division posed no threat to the impartial adjudication of "Cases" and "Controversies" because the Ethics Act prohibited the judges from participating in independent counsel judicial proceedings. ${ }^{138}$ His focus was solely on the Special Division's ability to affect specific adjudications. Judge Silberman's focus was broader. Article III judge participation in political disputes, he believed, undermined the public's confidence in an impartial judiciary. ${ }^{139}$ Interpretations of the Judicial Conduct Act also reflect this difference in analytical focus between the specific case and the reputation of the judiciary.

Judge Edwards's dismissal of the complaints because Article II conduct could not have "even an indirect prejudicial effect on the administration of the business of the courts"140 demonstrates a strict case-specific interpretation of the Judicial Conduct Act. Although Edwards is certainly not alone in his view of the Act's scope, ${ }^{141}$ such a formalistic interpretation does not accurately reflect the legislative history of the Act or the Act's application.

\section{The Legislative History of the Disciplinary Standard ${ }^{142}$}

The legislative history of the Act's substantive standard suffers, like the standard itself, from ambiguity. The ambiguity of the standard derives from its brevity and generality. The ambiguity of the legislative history, on the other hand, results from its mixture of competing and sometimes conflicting views about the proper scope of the disciplinary standard. Taken as a whole, though, these mingled congressional intentions support a conception of the Act's breadth that is larger than the "specific Article III case" interpretation.

The Senate version of what would become the Judicial Conduct Act, S. 1873, originally contained language that would have permitted a complaint to allege that the subject judge had engaged "in conduct prejudicial to the administration of justice by bringing the

138 See supra note 69 and accompanying text.

139 See supra note 60 and accompanying text.

${ }^{140}$ In re Charge of Judicial Misconduct or Disability, 39 F.3d 374, 379 (Judicial Council, D.C. Cir. 1994).

${ }^{141}$ See Barr \& Willging, supra note 135, at 73 (quoting a chief judge's statement that Congress "intended to limit jurisdiction under the Act to conduct adversely affecting judicial performance in some concrete manner"). The notion of "effect," however, is somewhat elastic.

142 For a detailed description of the Act's background and legislative history, see Burbank, supra note 34 , at 291-304. 
judicial office into disrepute."'143 This phrasing of the substantive standard, however, was deleted at the suggestion of Senator Birch Bayh (D-Ind.), "because it was felt that this standard could be too intrusive on the judge's personal life and was subject to possible abuse."144 Senator Bayh viewed the Act as having a limited jurisdiction: "Extrajudicial habits and behavior are outside the reach of the bill. It is only when a judge's behavior affects his performance on the bench that a complaint is valid." 45

The Senate Judiciary Committee's report on S. 1873 appeared to echo Senator Bayh's interpretation. In its statement of general principles, the report described conduct that is "not connected with the judicial office" or conduct that does "not affect the administration of justice" as outside the scope of the Act. ${ }^{146}$

Nevertheless, the report also approvingly cited state judicial disciplinary models that covered a great variety of conduct not directly related to the performance of official duties. ${ }^{147}$ The report stated that the standards of the Act were to be given their common usage and already existing statutory understanding:

Effective and expeditious administration of the business of the courts is language already found in Section 332 of Title 28 and is intended to include willful misconduct in office, willful and persistent failure to perform the duties of the office, habitual intemperence, and other conduct prejudicial to the administration of justice that brings the judicial office into disrepute. ${ }^{148}$

${ }^{143}$ Id. at 303 n.79 (quoting Hearings on S. 295, S. 522, S. 678 Before the Subcomm. on Judicial Machinery and Constitution of the Senate Comm. on the Judiciary, 96th Cong., Ist Sess. 494 (1979)).

144 CoNG. REC. 30,050 (1979) (statement of Sen. Thurmond).

145125 CONG. REC. 30,064 (1979) (statement of Sen. Bayh).

${ }^{146}$ S. REP. No. 362, 96th Cong., 2d Sess. 3 (1979), reprinted in 1979 U.S.C.C.A.N. 4315, 4317 [hereinafter SENATE REPORT].

${ }^{147}$ See id. at 8-9.

${ }^{143}$ Id. The particular language used in the Act was familiar to the judiciary. In 1961, the Judicial Conference approved a report on the powers and duties of the judicial councils which stated:

The responsibility of the Councils "for the effective and expeditious administration of the business of the courts within its circuit" extends not merely to the business of the courts in its technical sense (Judicial administration), such as the handling and dispatching of cases, but also to the business of the judiciary in its institutional sense (administration of justice), such as the avoiding of any stigma, disrepute, or other element of loss of public esteem and confidence in respect of the court system, from the actions of a judge or other person attached to the courts.

Burbank, supra note 34, at $294 \mathrm{n} .37$ (quoting Report of the Proceedings of the Judicial Conference of the United States 51 (Mar. 1961), reprinted in H.R. Doc. No. 201, 87th 
Describing the above terms as "terms of art" because of their usage in state disciplinary systems, the report expressly disavowed any attempt to add a "legislative gloss." 149 Thus, despite the deletion of the "disrepute" language from the Act's substantive standard, the Committee intended some species of disreputable, off-the-bench conduct to remain within the Act's scope.

The Senate Report further recommended reference to the ABA Canons of Judicial Ethics ${ }^{150}$ and the Code of Judicial Conduct for United States Judges in evaluating complaints. ${ }^{151}$ Canon 2A of the Code of Judicial Conduct states that a judge "should conduct himself at all times in a manner that promotes public confidence in the integrity and impartiality of the judiciary." ${ }^{152}$ Though they are merely nonbinding considerations under the Act, these ethical norms address judicial conduct outside and inside the courtroom and disapprove of judges engaging in partisan political activities. ${ }^{153}$

The House of Representatives committee report did not include a detailed description of the Act's substantive standard. What little description the report did provide supports the idea that Congress did not intend to limit the Act's scope to conduct in specific Article III cases. The standard was said to incorporate "complaints regarding impeachable behavior [and] violations of the criminal laws of any State or the United States."154 A strict Article III interpretation of

Cong., 1st Sess. 8-9 (1961)). The Conference reaffirmed this proposition in 1974. See id.

${ }^{149}$ SENATE REPORT, supra note 146 , at 9.

${ }^{150}$ See CANONS OF JUdicial ETHICS (1957), superceded by MODEL CODE OF JUDICIAL CONDUCT (1990).

151 See SENATE REPORT, supra note 146 , at 9.

152 CODE OF JUDICIAL CONDUCT Canon 2A. The complaints against Judge Sentelle used the "appearance of impropriety" language of Canon 2. In re Charge of Judicial Misconduct or Disability, 39 F.3d 374, 377 (Judicial Council, D.C. Cir. 1994).

${ }^{153}$ See, e.g., Judicial Conference of the United States, Interim Advisory Comm. on Judicial Activities, Advisory Op. No. 19 (1970) (stating that a judge should resign from a politically active club, even if the judge is not an active participant, because of the appearance of partisan activities); ABA Comm. on Ethics and Professional Responsibility, Informal Op. 867 (1965) (describing a judge's attendance and placement at the head table during a political fundraising dinner as "fraught with aspects of impropriety"); ABA Comm. on Ethics and Professional Responsibility, Formal Op. 312 (1964) (stating that a judge who becomes a candidate for judicial office should refrain from all conduct which might "tend to arouse reasonable suspicion that he is using the power or prestige of his judicial position to promote . . . the success of his party"); ABA Comm. on Ethics and Professional Responsibility, Formal Op. 113 (1934) ("[A] judge is entitled to entertain his personal views of political questions, but should not directly or indirectly participate in partisan political activities.").

${ }^{154}$ H.R. REP. No. 1313, 96th Cong., 2d Sess. 10 (1980) [hereinafter HOUSE 
the scope of the Act proves too little if criminal conduct off the bench is also covered. It is possible that this could still leave a large gray area of noncriminal, nonjudicial behavior beyond the Act's reach by virtue of Senator Bayh's concern for a judge's private life. ${ }^{155}$ The House report, however, observed that a valid complaint under the Act could involve "an allegation that several judges have engaged in activities demeaning to the bench; assume, for example, that after a meeting of a circuit's judicial conference, a large number of judges become intoxicated in a bar of ill repute."156 The report did not specify whether the judges' activity per se-being drunk in a bar of ill repute-brought them within the Act's scope or whether the determinative factor was the activity's temporal proximity to the circuit's judicial conference.

The legislative history of the Act, while inconclusive, suggests two things. First, most private behavior, "judge-as-citizen" behavior, is beyond the Act's scope. Second, the more disreputable the nonjudicial behavior, the more likely the Act will address it. ${ }^{157}$ Although the dividing line is unclear, Congress intended the Act to regulate some non-Article III conduct which brings the judicial office into disrepute. If the benchmark is how "official" the non-Article III conduct appears, abuse of Article II appointment power while on the Special Division should qualify for coverage. The panel is by statute a division of the D.C. Circuit. ${ }^{158}$ A member of the Special Division must be an Article III judge. His duties resemble those of a judge far more than a private citizen.

\section{The Disciplinary Standard in Practice}

The paucity of published orders makes it difficult to analyze comprehensively the judicial councils' application of the Act's disciplinary standard. ${ }^{159}$ It is possible, however, to glean some idea of the Act in practice from the limited published orders and scholarly commentaries. Because the Act places enforcement responsibility with the individual judicial councils, the application of the disciplinary standard has been varied and often conflicting. ${ }^{160}$

\section{REPORT].}

${ }^{155}$ See supra notes $144-45$ and accompanying text.

${ }^{136}$ HOUSE REPORT, supra note 154 , at 12.

${ }^{157}$ Criminal behavior falls easily on the side of inclusion.

153 See 28 U.S.C. § 49(a) (1994).

${ }^{159}$ See supra note 137.

${ }^{160}$ See Richard L. Marcus, Who Should Discipline Federal Judges, and How?, 149 F.R.D. 
It is perhaps unsurprising that the generality of the substantive standard and the ambiguity of the legislative history would yield such a result. ${ }^{161}$

As would be expected, the great majority of complaints and actions under the Act have involved conduct associated with specific Article III "Cases" or "Controversies." 162 As to conduct outside this setting, responses are mixed. Chief judges and judicial councils have dismissed complaints relating to comments by judges in speeches and newspapers, perjury allegedly committed prior to taking the bench, and participation in family members' legal actions. ${ }^{163}$ Judicial councils have also interpreted the Act to regulate some instances of politically partisan or highly disreputable conduct that is not directly related to a specific Article III dispute. In such cases, the fact that an Article III judge had allegedly committed the acts was the touchstone; the institutional setting was not.

The First Circuit Judicial Council found a judge's speeches endorsing statehood for Puerto Rico to be political conduct within the scope of the Act's substantive standard. ${ }^{164}$ The Sixth Circuit Judicial Council similarly considered valid a complaint about a judge's public statements concerning Congress's failure to increase judicial salaries. ${ }^{165}$ Although both proceedings were eventually

375, 401-02 (1993) (noting the lack of a "common law" under the Act and the fact that ${ }^{~}[t]$ here is presently no method for resolving consciously conflicting interpretations of the Act").

${ }^{161}$ Shortly before the Act became effective, Chief Judge James R. Browning of the Ninth Circuit described what he considered to be the administrative thrust of the Act: "The process is initiated not by alleging 'misconduct' or 'conduct that brings the judicial office into disrepute,' but by alleging 'conduct prejudicial to the effective and expeditious administration of the business of the courts.' Only time will determine the significance of these differences, but their significance may be great." James $R$. Browning, Evaluating Judicial Performance and Related Matters, 90 F.R.D. 197, 204 (1981).

${ }^{162}$ See Barr \& Willging, supra note 135 , at $49-50$ (presenting statistical data on the types of allegations filed).

${ }^{163}$ See Marcus, supra note 160 , at $404-07$ (summarizing the complaints and subsequent dismissals). One complaint alleged that a judge made racist comments in a newspaper article. Another centered on a judge's speech in which he called for the legalization of drug use. Yet another complaint arose in the course of a custody dispute between a judge's wife and her former husband. The ex-husband challenged the judge's reluctance to advise his fiancée to obey a court order to reveal her child's whereabouts. None of these dismissed complaints alleged partisan behavior. See id. at 404-06. Professor Marcus, while citing these dismissals, noted that the legislative history of the Act suggests that "behavior seemingly outside the judicial context is not per se immune to regulation." Id. at 404.

${ }^{164}$ See id. at 386.

${ }^{165}$ See id. at 387. 
concluded after "appropriate corrective action," 166 both complaints were found to be in conformity with the Act's substantive standard.

In another complaint, the chief judge of the Sixth Circuit concluded that a bankruptcy judge's serious indiscretions involving abusive language and conduct toward women both in court and, more frequently, in nearby bars and restaurants brought the federal judiciary into disrepute. ${ }^{167}$ Both the in-court and out-of-court behavior violated Canons 1 and 2 of the Code of Judicial Conduct and were thus subject to proceedings under the Act. ${ }^{168}$

The Illustrative Rules, published in 1986 to aid the implementation of the Act, described what types of complaints the Act authorized. Among other things, the disciplinary standard under the Act covered "use of the judge's office to obtain special treatment for friends and relatives." 169 This concept need not be stretched too far to encompass an Article III judge's use of a power exclusively vested in him by Congress to perform a politically partisan favor for an old friend. Practice under the Judicial Conduct Act suggests that a complaint about such behavior should not be dismissed outright.

\section{Chief Judge Edwards's Article II/Article III Distinction Is Inconsistent with the Judicial Conduct Act}

The Judicial Conduct Act's legislative history and application in other situations, although not univocal, suggest that Judge Edwards's formalistic distinction between Article II conduct and Article III conduct represents a departure from the Act's purposes. ${ }^{170}$ The Act applies predominantly to Article III conduct; that is the primary

16628 U.S.C. $\$ 372(\mathrm{c})(3)$ (B) (1994).

${ }^{167}$ See In re Harry G. Hackett, Unreported Findings and Report (6th Gir. June 24, 1981) reported in AMERICAN JUDICATURE SOC'Y, JUD. DISCIPLINE \& DISABILITY Dig.-POST 1980 SUPPLEMENTS, at FED2-3 (Yvette Begue ed., Jan. 1981-June 1986 Supp.).

${ }^{163}$ See id. Canon 1 provides: "A judge should uphold the integrity and independence of the judiciary" Canon 2 provides: "A judge should avoid impropriety and the appearance of impropriety in all activities." CODE OF JUDICIAL CoNDUCr Canons 1, 2. Whether the Act covers nonjudicial conduct seems to be a question of degree. See Marcus, supra note 160, at 406 (citing the Fourth Circuit Chief Judge's dismissal of a complaint about a judge's "rude" behavior in a dispute over a parking space).

169 ILLUSTRATIVE R. 1(b).

${ }^{170}$ It also conflicts with how a panel of the D.C. Circuit, in the main case upholding the Act's constitutionality, interpreted the substantive standard of the Act. See Hastings v. Judicial Conference, 829 F.2d 91, 106 (D.C. Cir. 1987) (quoting the Senate Report's assertion that the Act included "conduct prejudicial to the administration of justice that brings the judicial office into disrepute'"). 
business of the courts. But an action's classification in the constitutional scheme is not determinative of whether it is "prejudicial to the effective and expeditious administration of the business of the courts." ${ }^{171}$ The Act covers some disreputable conduct that, although it may have no Article III origin or relation, rises to a level at which some prejudicial effect could occur. Applying the Act to an allegedly political abuse of Article II appointment power by a member of the Special Division would neither violate the purpose of the Act nor impermissibly increase its scope.

Judge Edwards's conception would exclude from coverage under the Act any actions performed by a judge pursuant to a grant of power under Article I. The Supreme Court has described rulemaking power as originating in Article I. ${ }^{172}$ Federal judges, performing non-Article III duties, have contributed to the formulation of the Federal Rules of Civil Procedure, the Federal Rules of Criminal Procedure, the Federal Rules of Evidence, the Federal Sentencing Guidelines, as well as appellate and district court local procedural rules. If presented with evidence that a federal judge had engaged in some form of misconduct while on a rulemaking committee, it is unlikely that a judicial council would simply dismiss the complaint as not in conformity with the Act.

Federal judges also perform non-Article III duties when they naturalize aliens. ${ }^{173}$ Were a federal judge to preface a naturalization ceremony with a racist, xenophobic diatribe against the participants, it is likely that a judicial council would find a complaint about such behavior to be a valid one. Under Judge Edwards's theory of the substantive standard, this behavior could not be the subject of discipline.

17128 U.S.C. § 372(c)(1) (1994).

${ }^{172}$ See Mistretta v. United States, 488 U.S. 361,386 n.14 (1989) ("[R]ulemaking power originates in the Legislative Branch and becomes an executive function only when delegated by the Legislature to the Executive Branch."); see also Hanna v. Plumer, 380 U.S. 460, 472 (1965) ("[T] he constitutional provision for a federal court system [,] augmented by the Necessary and Proper Clause[,] carries with it congressional power to make rules governing the practice and pleading in those courts . ..."); Sibbach v. Wilson \& Co., 312 U.S. 1, 9-10 (1941) ("Congress has undoubted power to regulate the practice and procedure of federal courts, and may exercise that power by delegating to this or other federal courts authority to make rules not inconsistent with the statutes or [C] onstitution of the United States ...." (footnote omitted)).

${ }^{173}$ See 8 U.S.C. §§ $1447-48$ (1994); 36 U.S.C. § 154 (1994). 


\section{Abuse of the Special Division Appointment Power Should Fall Within the Ambit of the Judicial Conduct Act}

Neither the legislative history nor the subsequent application of the Judicial Conduct Act supports Judge Edwards's formalistic Article II/Article III distinction regarding the Act's substantive standard. Rather, both support a substantive standard that would encompass Judge Sentelle's behavior on the Special Division. Only Article III judges can be members of this special panel of the D.C. Circuit. Their activities are intimately related to potential Article III "Cases" and "Controversies." Application of the Judicial Conduct Act to Special Division activities would not intrude upon a judge's personal life, nor would it impermissibly expand the Act's scope.

Thus, there is in fact a simple solution to Justice Scalia's concern in Morrison that there would be no remedy for politically motivated abuse of the Special Division's appointment power. ${ }^{174}$ Such abuse should fall within the disciplinary ambit of the Judicial Conduct Act.

\section{CONCLUSION}

The Senate Report on the Judicial Conduct Act stated that " $[t]$ he perception of justice is of critical importance."175 Despite Judge Edwards's dismissal of the complaint against Judge Sentelle, it remains the case that, in the eyes of many, a federal judge abused governmental appointment power. The public saw a judge-not an ordinary citizen or a legislator or a member of the executive branch. As former ABA President Robert $D$. Raven described it, "[the] point is whether the vast majority of the public would believe there is an appearance of impropriety. The distinction between Article II or Article III is probably known by most judges and some lawyers but by very few members of the public."176

The perceived abuse of Special Division appointment power, left unchecked, could undermine the public's confidence in the neutrality of the judiciary. A real abuse of that power could result in prosecutorial violations of constitutional rights. The sensible application of the Judicial Conduct Act to the members of the Special Division would provide an effective defense against both threats.

${ }^{174}$ See Morrison v. Olson, 487 U.S. 654, 729-31 (1988) (Scalia, J., dissenting).

175 SENATE REPORT, supra note 146 , at 7.

${ }^{176}$ Henry J. Reske, Lunch Not Unethical: Judge Rules on Sentelle Complaints, A.B.A. J., Jan. 1995, at 27, 27. 
